\title{
Digitális intelligencia - készségek a sikeres digitális élethez
}

\section{Digitális intelligencia - készségek a sikeres digitális élethez}

Az intelligencia az irodalmi kutatások ${ }^{1}, a^{2}$ az Wechsler szingularista felfogása szerint „,az egyénnek az az összesített, vagy globális képessége, amely lehetővé teszi a célszerü cselekvést, a racionális gondolkodást és a környezettel való eredményes bánást."

A pluralista felfogás szerint legismertebb Gardner 7 féle értelme: szóbeli, logikai, térbeli, zenei, kinetikus (mozgásos), interperszonális (személyközi) és intraperszonális (személyen belüli) képességeket.

Sternberg 3 oldalú megközelítésében az ismeretszerzési, teljesítmény, metakomponensek játszanak szerepet. Cattel kétféle intelligenciát különít el: hajlékony és rögzült intelligenciát. Összefoglalva: intelligencia alatt a képességeket értjük, amelyek szükségesek az új ismeretek és készségek elsajátítására és alkalmazására.

\footnotetext{
${ }^{1}$ https://uni-eszterhazy.hu/hefoppalyazat/pszielmal/az_intelligencia_fogalma.html In: Dr. Estefánné dr. Varga Magdolna, Dr. Dávid Mária, Dr. Hatvani Andrea, Dr. HéjjaNagy Katalin, Taskó Tünde: Pszichológia elméleti alapok
} 
Napjainkban a digitális átállás, új gondolkodási módot igényel. A digitális intelligencia szükséges a tevékenység hatékony és eredményes teljesítéséhez.

Amint belépünk egy olyan korszakba, amelyet egyre inkább digitális eszközökkel végzünk, újfajta intelligenciára van szükségünk, tehát folyamatosan fejlődik.

A digitális intelligencia egyszerü meghatározása "a digitális technológiákkal kapcsolatos új ismeretek és készségek elsajátítása és alkalmazása". Ez több mint a digitális eszközök használatának képessége. Digitális intelligencia alatt értendő, hogy miért, mit, mikor tudja a digitális technológiát a hatékonyság és a kimenetek javítása érdekében helyesen alkalmazni az egyén. A digitális intelligencia nem a digitális eszközök használatáról szól az emberi képességek kizárásával, hanem inkább az emberek és a technológia viszonylagos erősségeiröl.

Az utóbbi években a digitális eszközökhöz való hozzáférés ugrásszerüen megnőtt a Facebook, Twitter és egyéb közösségi eszközök által is. Az információnk a felhőalapú mentési szolgáltatásainkkal mindenhol elérhetővé válnak, például a Dropbox és az Evernote segítségével.

A digitális intelligencia (DQTM) alatt értendő tehát, a digitális életvitelhez szükséges technikai, szellemi és társadalmi kompetenciák összessége. Ez magában foglalja azokat az ismereteket, készségeket, attitüdöket és értékeket, amelyek szükségesek az online világ felelős tagjaként való követelmények teljesítéséhez és az egyén a technológia adta lehetőségek céltudatos és felelősségteljes alkalmazásához.

A mai társadalom feladata, hogy az állampolgárok digitális intelligencia terén történő képzésével és felkészítésével a kulcsfontosságú programhoz való eredményes csatlakozását segítse.

A digitális érzelmi intelligencia, a digitális egyensúly és a digitális magabiztosság elemei ${ }^{2}$

„A Digital Intelligence, azaz DQ projekt egy - elsősorban - délkelet-ázsiai országok együttmüködésével létrejött kutatási projekt, amelybe azonban bárki bekapcsolódhat.

A $\mathrm{K}+\mathrm{F}$ projekt alapvető célja, hogy a digitális intelligenciát vizsgálja, illetve pilot kísérletek által kísérletet tegyen az elméleti modell igazolására. A projekt 2016 júliusában indult, egyelőre 14 országban.”

${ }^{2}$ http://mipszi.hu/hir/160906-hogyan-epul-fel-digitalis-intelligencia 
A TÉR / IDŐ blog felületen magyarul is olvashatunk a projektről. A blog szerzője, Farkas Bertalan Péter, aki a World Economic Fórumon jelenteti meg anyagát. A projekt keretében egy önálló tanuláshoz és osztálytermi oktatáshoz is jól felhasználható online angol nyelvü tananyag a weben elérhetö ${ }^{3},{ }^{4}$.

A pedagógusok, szülők, oktatási döntéshozók számára is fontos tudást nyújtó képzési anyagot és az általa elsajátított ismeretet, mint a digitális intelligencia 8 készsége (mindegyik egy-egy készségcsomag valójában), a sikeres digitális léthez gyermekeinknek el kell sajátítani. A projekt keretében egy önálló tanuláshoz és osztálytermi oktatáshoz is jól felhasználható online tananyagot is biztosít a felület: http://www.dqproject.org/és a http://www.izhero.net/

\subsection{A digitális intelligencia felépítése}

A digitális intelligencia 8 készségcsomagból épül fel, amelynek összetételét az alábbi kördiagram szemlélteti:

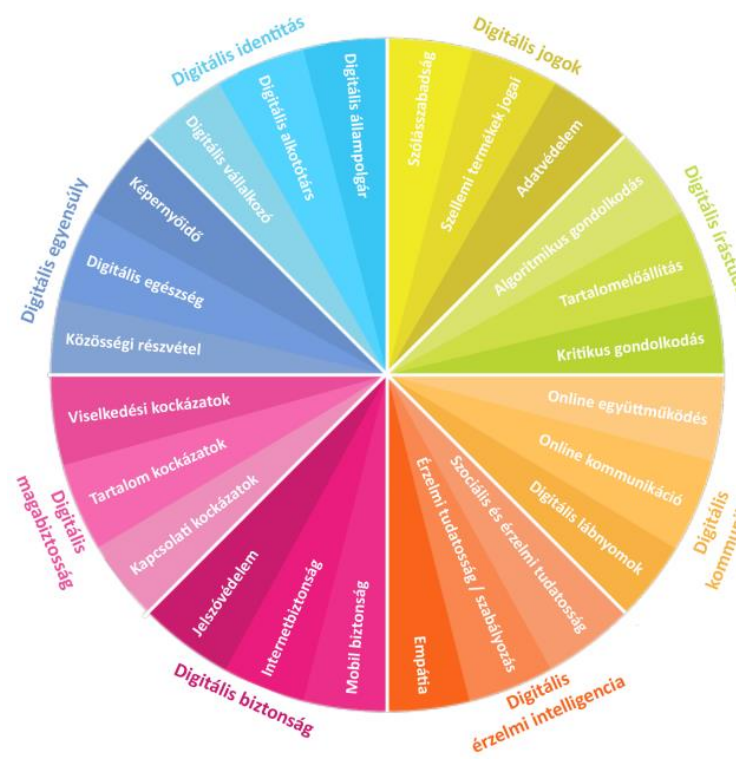

A digitális intelligencia készségei.

Fordította és az ábrát készítette: Farkas Bertalan Péter.

Forrás: http://moderniskola.hu/2016/09/hogyan-epul-fel-digitalis-intelligencia/

\footnotetext{
${ }^{3}$ http://www.dqproject.org/

${ }^{4}$ http://www.izhero.net/
} 
A digitális intelligencia értelmezése ${ }^{5}$ :

1. Digitális identitás: magában foglalja az egyén online jelenlétét, illetve az online jelenlétének és magatartásának rövid-, illetve hosszú távú menedzselésének képességét. Elemei: digitális állampolgár, digitális alkotótárs, digitális vállalkozó

2. Digitális egyensúly: a digitális eszközök és médiakontrollált használata az offline és online élet közötti egészséges egyensúly elérése érdekében. Elemei: képernyőidő, digitális egészség, közösségi részvétel

3. Digitális magabiztosság: az online kockázatok (cyberbullying, radikalizáció) és az online megjelenő problémás tartalmak kezelésének képessége, beleértve ezek elkerülésének és kordában tartásának készségét is. Elemei: viselkedési kockázatok, tartalom kockázatok, kapcsolódási kockázatok

4. Digitális biztonság: a kiberfenyegetések (hackelés, online csalások, adathalászat, malware támadások) felismerésének képessége, illetve az adatvédelemhez szükséges megfelelő és testhezálló módszerek megtalálásának képessége. Elemei: jelszóvédelem, internetbiztonság, mobilbiztonság

5. Digitális érzelmi intelligencia: az empátia és a jó online kapcsolatok kiépítésének képessége. Elemei: szociális és érzelmi tudatosság, érzelmi tudatosság/szabályozás

6. Digitális kommunikáció: a másokkal való kommunikáció és együttmüködés képessége a technológia és a média használatával. Elemei: online együttműködés, online kommunikáció, digitális lábnyomok

7. Digitális írástudás: képességek összessége, amelyek lehetővé teszik a megfelelő tartalmak megtalálását, értékelését és használatát, algoritmikus gondolkodás segítségével. Elemei: kritikus gondolkodás, tartalomelőállítás, algoritmikus gondolkodás

8. Digitális jogok: képesség arra, hogy megértsék és támogassák a személyes és törvény által biztosított jogokat, beleértve a magánélethez való jogot, a szellemi tulajdon védelmét, a szólásszabadságot, illetve a

\footnotetext{
${ }^{5}$ http://moderniskola.hu/2016/09/hogyan-epul-fel-digitalis-intelligencia/
} 
gyülöletbeszéd elleni védelmet. Elemei: adatvédelem, szellemi termékek jogai, szólásszabadság

A digitalizáció során ki kell használni azon képességeinket, készségeinket, amelyek a rendelkezésünkre álló lehetőségek alkalmazását segítik. A munkaerőpiacnak megfelelő, digitális képességekkel rendelkező fiatalokra van szükség. A fiataloknak a digitális müveltség mellett digitális iránytüre is szüksége van, amely megmutatja az utat a digitális világban. El kell sajátítania a digitális világ kritikus használatát. Az oktatásnak elsődleges szerepe van a kialakításában. TÉR / IDŐ blog ${ }^{6}$ magyar nyelven foglalkozik a kérdéssel (Farkas Bertalan Péter a szerző, a World Economic Fórum tagja).

\section{Digitális intelligencia oktatásának gyakorlata, nemzetközi minták alapján}

Az IQ-hoz és az EQ-hoz (érzelmi intelligencia) hasonlóan az is mérhető, hogy képes-e az ember hozzáférni a digitális médiához és képes-e megfelelően, biztonságosan és produktívan bánni vele. Ezt DQ-nak, digitális intelligenciának nevezzük. A digitális intelligencia fejleszthetö.

2.1 Yuhyun Park, egy koreai biológa-informatika tanár, két gyermek édesanyja. A tapasztalatait a gyermekei viselkedése, szokásai alapján összegzi. Elemzi, hogy számtalan információval szembesülhet egy kiskorú internethasználat közben. Egy alapítványt hozott létre Infollution Zero néven (infolluton = information, pollution, információszennyezés), azzal foglalkozik, hogy „felelős internetpolgárokká" nevelje a gyerekeket. Célja, hogy a felhasználók már óvodáskoruktól tisztában legyenek olyan veszélyekkel, mint a cyberbullying, a videójáték-függőség és az arctalan „barátok”.

Az Infollution Zero rávilágít és tanácsokat ad a gyerekeknek, hogy miként alakítsanak ki bátor, hatékony és felelős internetezési szokásokat a házi feladat elkészítésekor, hogyan használják a Facebook-ot. Yuhyun összefoglalja tanulmányában a digitális intelligencia összetevőit:

\footnotetext{
${ }^{6}$ https://terido.wordpress.com/
} 


\section{1. szint: digitális állampolgárság}

A digitális állampolgár képes biztonságosan, felelősen és hatékonyan használni a digitális technológiát.

\section{2. szint: digitális kreativitás}

Digitálisan kreatív az, aki képes a digitális ökoszisztéma részévé válni, új tartalmat létrehozni (vagy annak létrehozásában részt venni) és digitális eszközök használatával megvalósítani az ötleteit.

\section{3. szint: digitális vállalkozói szellem}

Ezen képesség „birtokosa” arra tudja használni a digitális médiát és technológiákat, hogy globális problémákat oldjon meg és új lehetőségeket teremtsen.

Yuhyun szerint a DQ első szintjét, a digitális állampolgárságot, sokszor elhanyagolják vagy alábecsülik, és a családokban, iskolákban, állami tantervekben kevesebb figyelmet fordítanak a felelös gondolkodásra internethasználat közben, mint kellene. A következő digitális készségeket kellene minden gyereknek megtanulnia a digitális intelligencia „megalapozásához”:

- Digitális állampolgár-identitás: Ki vagyok én a digitális világban és ki vagyok a valóságban? Mennyire tudom összeegyeztetni a kettőt?

- Képernyő-time management: Egy felelős digitális állampolgárnak tudnia kell bánni a képernyő előtt töltött idejével. Elöre „meg kell beszélnie magával", hogy mennyi időt tölt játékkal és mennyit a közösségi oldalakon.

- Cyberbullying elleni védelem: Minden 6-13 év közötti gyereknek fel kell tudnia ismerni a digitális zaklatást és józan ésszel kezelni azt.

- Online biztonsági intézkedések: Már a gyerekeknek is tudatosan kell bánniuk az alapvető adatvédelmi kérdésekkel, erős jelszavakat használva és kivédve az online támadásokat.

- A magánélet védelme: A digitális intelligencia azt is jelenti, hogy meg kell tudni védeni a személyes információkat. Helyesen kell reagálni a következő kérdésekre: Mi számít személyesnek? Kinek adhatjuk ki és kinek nem? Mi történik, ha mások személyes információinak birtokába jutunk? 
- Kritikus gondolkodás: Melyik információnak higgyünk az interneten és melyik a kacsa? Melyik tartalom hasznos és melyik kártékony? Melyik oldalban bízhatunk meg és melyik az, amelyiken túl sok a megkérdőjelezhető tartalom? Minél több, ehhez hasonló kérdésre tudunk megbízhatóan válaszolni, annál megbízhatóbb digitális polgárok leszünk.

- Digitális lábnyom: A „magas DQ”-val rendelkező digitális állampolgár képes megérteni, mit jelent, hogy digitális lábnyomot hagyunk magunk után, amikor az internetet használjuk. Mi az, ami örökre ott maradhat a világ különböző pontjain található szervereken? Egy digitális állampolgárnak felelősen kell ,gondoznia" a digitális lábnyomát.

- Digitális empátia: Képesnek kell lennünk arra is, hogy empátiát tanúsítsunk a saját és mások szükségletei iránt internethasználat közben.

Yuhyun Park szerint az iskoláknak nem csak a számítógép alkatrészeit vagy a böngészők használatát, hanem DQ-t is oktatni kell. A gyerekek már csecsemőkoruktól nap mint nap használják az internetet, a szülök okostelefonjáról, az esti mese közben véletlenszerủen felbukkanó reklámoktól a Youtube-on beugró reklámokon át hatnak a személyiségre. Az oktatási tevékenységet minél előbb el kell kezdeni, hívja fel a figyelmet a szerző.

2.2. A Digital Intelligence (DQ) projekt nemzetközileg elismert szakemberek és szervezetek együttműködésére épülve alakult meg. Elkötelezettek a jövö generáció ${ }^{7}$ képzésében, külön figyelmet fordítva a digitális környezet javítására.

A nemzetközileg elismert szakemberek és szervezetek által vezetett Digital Intelligence (DQ) projekt a digitális intelligenciát olyan szociális, érzelmi és kognitív képességek összességeként definiálja, amelyek alapvetőek a digitális élethez. Kutatásalapú és díjnyertes DQ világ e-learning programja digitális állampolgári oktatást kínál 8-12 éves korosztály számára. Feladatnak tekintik az ideális, digitális szülői stílus alapvető jellemzőinek kidolgozását és kialakítását.

Ide tartozik a tudás, valamint az olyan készségek és képességek, amelyek segítik az érzelmek dekódolását, illetve a viselkedés szabályozását, és amelyek szükségesek ahhoz, hogy kezelhetők legyenek a digitális kor kihívásai és igényei.

\footnotetext{
${ }^{7}$ www.pixabay.com
} 
Ezeknek a képességeknek a tudáson felül olyan emberi értékekben kell gyökerezniük, mint az empátia, tisztelet, becsületesség és a megfontoltság. Ezek az értékek lehetővé teszik a technológia bölcs és felelős használatát, amely - a remények szerint - jellemezni fogja a jövő vezetöit. Az első generáció éri el a felnőttkort, akik a digitális világba születtek.

A projekt célja ${ }^{8}$, hogy minden gyermeket képessé tegyen arra, hogy digitális vezetőkké váljanak - olyan egyénekké, akiket erős identitás és pozitív értékek jellemeznek, hogy ök, mint a technológia mesterei, képesek új lehetőségeket teremteni egy jobb jövő érdekében.

A digitális intelligencia három szintjét emeli ki a projekt:

- vezetés,

- kreativitás,

- vállalkozó szellem.

\section{A folyamat lépései:}

1. A tanulók a technológia felelős és hatékony használatát alkalmazva a digitális állampolgárság normáit sajátítják el.

2. A digitális kreativitás alkalmazásával, új technológiák használatával hozzájárulnak új tartalmak megteremtéséhez és az ötleteik megvalósításával folytatják a tevékenységet.

3. Végül a digitális vállalkozói szellemiség szintjén képessé válnak a változásokat előidézni és problémákat megoldani.

\section{3. eTwinning}

Az elméleti alapokat Marc Prensky ${ }^{9}$ munkássága alapozza meg. Pensky a digitális világot térként határozza meg a munkásságában, a digitális eszközök használóit a tér polgáraiként értelmezi. Ebben a térben nincsenek határok és nincs szükség útlevélre.

\footnotetext{
${ }^{8}$ www.dqinstitute.org

${ }^{9}$ Pensky, M (2001), Digital Natives, DigitalImmigrants. On The Horizon, 9(5) https://www.marcprensky.com/writing/Prensky\%20\%20Digital\%20Natives, \%20Digital\%20Immigrants\%20-\%20Part1.pdf
} 
A digitális polgárságnak 3 pillére van, a valahová tartozás, aktív szerepvállalás és biztonság. Feladat, hogy a digitális technológiák nyújtotta elönyöket hatékonyan és biztonságosan alkalmazzák.

A diákok digitális képességét a szerint csoportosítják, hogy milyen termékenyen hoznak létre digitális tartalmakat. Kiemelik annak fontosságát, hogy ne csak felhasználók legyenek, hanem a tartalmak alkotóivá váljanak, algoritmikus gondolkodásuk kialakuljon. Az európai iskolában 2016-ban indították az eTwining programot, amelynek központi feladata a kölcsönös tisztelet és az interkulturális megértés fejlesztése. 2016-ban több mint 20 program indult, amelynek központi témája a digitális állampolgárság.

\section{A digitális részvétel 4 lépcsőfokát különböztetik meg.}

Első fok: azok a tanulók, akik rejtett módon vesznek részt a digitális világban.

Második fokon azok állnak, akik a digitális világot fogyasztóként és szemlélőként használják. Információkat, tartalmakat osztanak meg, kapcsolatokat teremtenek.

Harmadik fok: akik új tartalmakat, eszközöket hoznak létre, új módszereket vezetnek be a kapcsolat tartásához, a digitális társadalomban való részvételhez.

Negyedik fok: azok tartoznak ide, akik hasznosítják a technológiában rejlő lehetőségeket, aktívan formálják az internet jövőjét.

\section{A projekteket 3 csoportba lehet osztani:}

- A digitális polgárok készségei és képességei: hangsúlyt kap a nyitottság és együttmüködés.

- Aktív részvétel és szerepvállalás: mindnyájunkat érintő kérdések kapnak szerepet.

- A technológiák biztonságos és felelősségteljes használata: azon stratégiák és módszerek alkalmazása, amelyek biztosítják a pedagógusok és diákok biztonságos és felelősségteljes részvételét a digitális világban. 


\section{Projektek:}

\section{Digitális polgárok készségei, képességei}

- Interaktív európai útvonal 33 partneriskola, 10-16 évesek számára

- A nyelvtanulás mágusai 15 partneriskola 9-1 évesek számára

- Fogyatékosságot befogadó iskolák 12 partneriskola, 7-16 évesek számára

\section{Nyitottság és együttmüködés}

- Készen állsz arra, hogy a 21. században élj? 6 partneriskola, 8-12 évesek számára

- Digitális polgárság mindenkinek 53 partneriskola, 3-20 évesek számára

- Digitális életvezetési kísérletek az európai iskolai rádióban, 4 partneriskola, 10-11 évesek számára

- Az európai polgárságra nevelés a médián keresztül, 34 partneriskola, 1218 évesek számára

- Mi újság Európában? 8 partneriskola, 16-17 évesek számára

- Kulturális sokszínűség-egy szív, 2 partneriskola, 13-14 évesek számára

- Mi van a talpunk alatt? 5 partneriskola, 3-5 évesek számára

- Az utazás kitágítja gondolkodásunkat - Gyertek teremtsünk egy projekttel társadalmi szolidaritást - COMPASS 12 partneriskola, 12-15 évesek számára

- Lányok és az IKT, 51 partneriskola, 10-19 évesek számára

- Vigyázat jövünk! 2 partneriskola, 16-19 évesek számára

\section{Aktív részvétel, szerepvállalás}

- Az én világom, az én tantermem, 46 partneriskola, 11-14 évesek számára

- Vigyázz, kész, lassú növekedés- idő és készségek ráfordítása a fenntartható európai polgárság számára,14 partneriskola, 12-19 évesek számára

- Értékek a gyakorlatban, 18 partneriskola, 4-12 évesek számára 
- Európa mi vagyunk - éljünk együtt békében, 5 partneriskola, 16-18 évesek számára

- A béke kultúrája az európai polgárság körében, 15 partneriskola, 6-16 évesek számára

- Egyenlö jogok - Ellenségeskedés és erőszak nélkül, 10 partneriskola, 15-19 évesek számára

\section{Demokráciával és az aktív polgári szerepvállalással foglalkozó projektek}

- Különböző útvonalak, de közös demokratikus értékek, 5 partneriskola, 15-18 évesek számára

- Szolidaritás határok nélkül, 22 partneriskola, 15-19 évesek számára

- Mitteninander statt nebeneinander, 24 partneriskola, 16-19 évesek számára

- Diákjaink képesek változtatni, 10 partneriskola, 14-18 évesek számára

- Mit gondolsz, te ki vagy? - Kutassuk fel közösen gyökereinket! 5 partneriskola, 11-16 évesek számára

- Viseld gondját környezetemnek, 5 partneriskola, 8-13 évesek számára

- Euró-újrahasznosítás, 7 partneriskola, 9-11 év

- Víz-globális kísérletezés a hidrogénekkel, 133 partneriskola, 5-18 évesek számára

- Víz-tartsd hüvösen-maradj melegen, 21 partneriskola, 10-12 évesek számára

- Zöld nyomozó, 6 partneriskola, 5-11 évesek számára

\section{E-biztonsággal foglalkozó projektek}

- Biztos, ami e-biztos, 8 partneriskola, 12-15 évesek számára

- Medienkoffer, 6 partneriskola, 11-16 évesek számára

A projekt eredményei a weboldalukon ${ }^{10}$ elérhető.

\footnotetext{
${ }^{10}$ https://www.etwinning.net/hu/pub/index.htm
} 
Az eTwinning magyarországi Szolgáltató Pontja minden évben verseny hirdet magyar pedagógusok számára ${ }^{11}$. Több csapat esetén előválogató alapján indulnak a csapatok.

Az intelligencia témájával, az elméleti és mérésmetodikai kérdéseivel Csépe Valéria, Győri Miklós és Ragó Anett foglalkozik ${ }^{12}$.

${ }^{11} \mathrm{http}: / /$ hirmagazin.sulinet.hu/hu/etwinning/etwinning-magyarorszag-verseny-2017felhivas 12

http://www.tankonyvtar.hu/hu/tartalom/tamop425/2011_0001_520_altalanos_pszichol ogia 3/ch18s02.html 


\section{Irodalom}

Az eTwinning az európai iskolák közössége. (dátum nélk.). Letöltés dátuma: 2020. január 24, forrás: eTwinning: https://www.etwinning.net/hu/pub/index.htm

Csépe Valéria, Győri Miklós, \& Ragó Anett. (2008). Általános pszichológia 3. Nyelv, tudat, gondolkodás. Budapest: Osiris.

Digital Intelligence Quotient. (dátum nélk.). Letöltés dátuma: 2018. április 18, forrás: DQ: http://www.dqproject.org/

DQ Institute. (dátum nélk.). Letöltés dátuma: 2020. január24, forrás: DQ Institute: http://www.dqinstitute.org/

DQ World. (dátum nélk.). Letöltés dátuma: 2020. január 24, forrás: DQ World: https://us.dqworld.net/\#!/landing

Estefánné Varga Magdolna, Dávid Mária, Hatvani Andrea, Héjja Nagy Katalin, \& Taskó Tünde. (2001). Pszichológia elméleti alapok. Eger. Forrás: https://uni-eszterhazy.hu/hefoppalyazat/pszielmal/index.html

eTwinning Magyarország Verseny 2017 - felhívás. (2017). Letöltés dátuma: 2020. január 24, forrás: Sulinet: https://hirmagazin.sulinet.hu/hu/etwinning/etwinning-magyarorszagverseny-2017-felhivas

Farkas Bertalan Péter. (2016). Hogyan épül fel a digitális intelligencia? A TÉR / IDÖ blog most bemutatja. Letöltés dátuma: 2020. január 25, forrás: http://moderniskola.hu/2016/09/hogyan-epul-fel-digitalis-intelligencia/

Farkas Bertalan Péter. (dátum nélk.). TÉR / IDÖ. Letöltés dátuma: 2020. január 24, forrás: TÉR / IDÖ: https://terido.wordpress.com/

Hogyan épül fel a digitális intelligencia? (dátum nélk.). Letöltés dátuma: 2020. január 22, forrás: Mindennapi pszichológia: https://mipszi.hu/hir/160906hogyan-epul-fel-digitalis-intelligencia

Prensky, M. (2001). Digital Natives, Digital Immigrants. On the Horizon, 9.(5.), 1-6. https://doi.org/10.1108/10748120110424816 